\title{
Liver transplant, toxoplasmosis and kidney stones: connecting the dots
}

\author{
Harini Bejjanki, ${ }^{1}$ Olanrewaju A Olaoye, ${ }_{1}^{2}$ Alfonso $\mathrm{H} \mathrm{Santos}^{2}{ }^{2}$ Abhilash Koratala ${ }^{2}$
}

'Department of Medicine, University of Florida, Gainesville, Florida, USA

${ }^{2}$ Department of Nephrology, University of Florida College of Medicine, Gainesville, Florida, USA

\section{Correspondence to} Dr Abhilash Koratala, akoratsla@ufl.edu

Accepted 28 January 2019

\section{DESCRIPTION}

A 62-year-old woman with a history of orthotopic liver transplantation for cirrhosis secondary to auto-immune hepatitis 3 months prior, presented with fever and new-onset seizures. Her maintenance immunosuppressive therapy included mycophenolate mofetil $500 \mathrm{mg}$ twice a day, tacrolimus $1 \mathrm{mg}$ twice a day and prednisone $5 \mathrm{mg}$ per day. Aerosolised pentamidine was being used for post-transplant Pneumocystis jirovecii prophylaxis instead of the standard therapy with trimethoprim-sulfamethoxazole because of recurrent episodes of serum creatinine elevation and hyperkalaemia in the immediate post-operative period. MRI of the brain demonstrated approximately $1.8 \times 1.9 \times 2.2 \mathrm{~cm}$ ring enhancing lesion in the right posterior frontal lobe with significant surrounding vasogenic oedema figure 1. Cerebrospinal Fluid (CSF) analysis showed lymphocytic pleocytosis but was negative CSF toxoplasma polymerase chain reaction. Due to high clinical suspicion, ring enhancing lesion on MRI and positive toxoplasma serum IgG, she was diagnosed with cerebral toxoplasmosis and initiated on sulfadiazine $1000 \mathrm{mg}$ every 6 hours, Pyrimethamine and Leucovorin. ${ }^{12}$ Repeat MRI of the brain 3 weeks after initiation of Sulfadiazine showed improvement in the size of the lesion and vasogenic oedema suggesting response to treatment and therefore, biopsy was not pursued. Around the same time, the patient developed gross haematuria, flank pain and mild acute Kidney Injury with a serum creatinine $1.3 \mathrm{mg} / \mathrm{dL}$ (baseline $\sim 0.9$ ). A renal sonogram

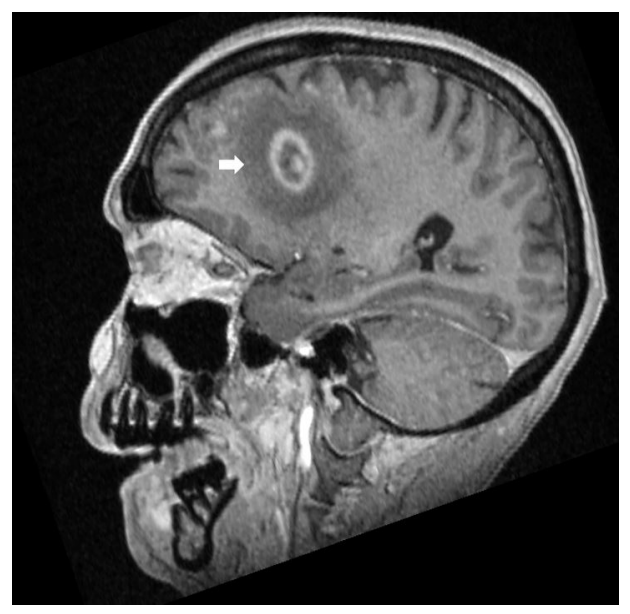

Figure $1 \mathrm{MRI}$ of the brain demonstrating approximately $1.8 \times 1.9 \times 2.2 \mathrm{~cm}$ rim-enhancing nodule in the right posterior frontal lobe with surrounding vasogenic oedema (arrow) suggestive of cerebral toxoplasmosis.
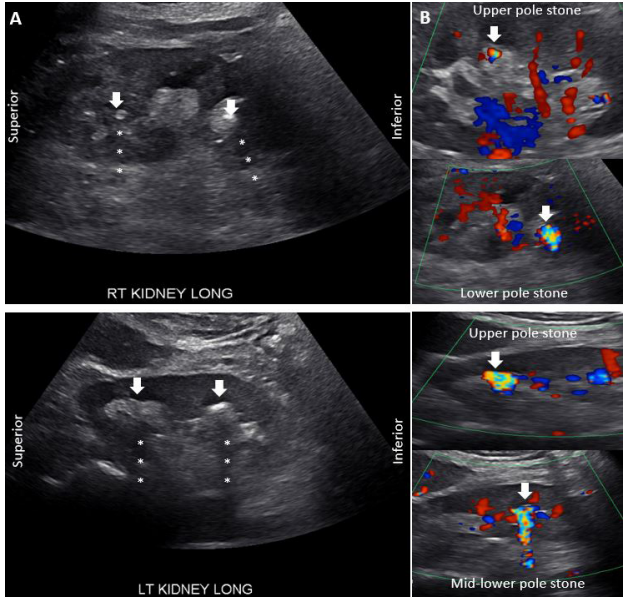

Figure 2 (A) Renal sonogram 3 weeks after starting sulfadiazine demonstrating nephrolithiasis (arrows). Acoustic shadowing (asterisks) refers to the black area seen beyond the stones (structures that do not transmit ultrasound waves). (B) On doppler mode, stones exhibit twinkling sign, which is a rapidly alternating focus of colour Doppler signals mimicking turbulent flow (arrows). This sign is helpful when the shadowing is not apparent. LT, left; RT, right.

Learning points

- Toxoplasma polymerase chain reaction testing in the Cerebrospinal Fluid has high specificity but variable sensitivity depending on the primer used. Therefore, it would be prudent to proceed with the treatment when the suspicion for cerebral toxoplasmosis is high.

- Aerosolised pentamidine, which our patient was receiving is not recommended for Toxoplasma prophylaxis. The data on prevention of toxoplasmosis is sparse and trimethoprimsulfamethoxazole at a dose of one doublestrength tablet three times/week is thought to be sufficient for both Pneumocystis and Toxoplasma prevention.

- Sulfonamide antibiotics such as sulfadiazine are relatively insoluble in acid urine, especially when used in high doses to treat toxoplasmosis, which may lead to crystal-induced acute kidney injury (crystalline nephropathy) and/ or nephrolithiasis from intrarenal drug precipitation. Alkalinisation of the urine to a $\mathrm{pH}$ more than 7.15 increases sulfadiazine solubility considerably. 
was obtained which showed non-obstructing bilateral renal stones with the classic acoustic shadowing and twinkling sign ${ }^{3}$ figure 2. She did not have known history of nephrolithiasis and review of CT of the abdomen prior to transplant confirmed the same. Urinalysis was significant for a $\mathrm{pH}$ of 5, 16 red blood cells per high power field and multiple hyaline casts. These findings were attributed to sulfadiazine-induced nephrolithiasis and the drug was transitioned to atovaquone. ${ }^{4-6}$ She was started on oral alkali supplementation to alkalinise the urine and her symptoms resolved in less than a week. A repeat renal sonogram obtained 6 months later demonstrated complete resolution of stones, retrospectively confirming the diagnosis of drug-induced nephrolithiasis.

Contributors HB: drafted the initial manuscript. OAO, AHS: guided patient management decisions, reviewed the manuscript. AK: reviewed and revised the manuscript for critically important intellectual content.

Funding The authors have not declared a specific grant for this research from any funding agency in the public, commercial or not-for-profit sectors.
Competing interests None declared.

Patient consent for publication Not required.

Provenance and peer review Not commissioned; externally peer reviewed.

\section{REFERENCES}

1 Antinori A, Ammassari A, De Luca A, et al. Diagnosis of AIDS-related focal brain lesions: a decision-making analysis based on clinical and neuroradiologic characteristics combined with polymerase chain reaction assays in CSF. Neurology 1997;48:687-94.

2 Nogui FL, Mattas S, Turcato Júnior G, et al. Neurotoxoplasmosis diagnosis for HIV-1 patients by real-time PCR of cerebrospinal fluid. Braz J Infect Dis 2009;13:18-23.

3 Koratala A, Vangapalli A, Bhattacharya D, et al. Bladder stone: "must know" ultrasonographic signs. Clin Case Rep 2019;170.

4 Baden LR, Katz JT, Franck L, et al. Successful toxoplasmosis prophylaxis after orthotopic cardiac transplantation with trimethoprim-sulfamethoxazole. Transplantation 2003;75:339-43.

5 Hein R, Brunkhorst R, Thon WF, et al. Symptomatic sulfadiazine crystalluria in AIDS patients: a report of two cases. Clin Nephrol 1993;39:254-6.

6 Simon DI, Brosius FC, Rothstein DM. Sulfadiazine crystalluria revisited. The treatment of Toxoplasma encephalitis in patients with acquired immunodeficiency syndrome. Arch Intern Med 1990;150:2379-84.

Copyright 2019 BMJ Publishing Group. All rights reserved. For permission to reuse any of this content visit

https://www.bmj.com/company/products-services/rights-and-licensing/permissions/

BMJ Case Report Fellows may re-use this article for personal use and teaching without any further permission.

Become a Fellow of BMJ Case Reports today and you can:

- Submit as many cases as you like

- Enjoy fast sympathetic peer review and rapid publication of accepted articles

- Access all the published articles

Re-use any of the published material for personal use and teaching without further permission

For information on Institutional Fellowships contact consortiasales@bmjgroup.com

Visit casereports.bmj.com for more articles like this and to become a Fellow 